УДК 330.88

ББК 65.02

РЕФОРМИРОВАНИЕ ИНСТИТУТОВ В РАМКАХ ИНТЕГРАЦИОННОГО ОБЪЕДИНЕНИЯ: ТЕОРИЯ И ПРАКТИКА ДЛЯ БЕЛАРУСИ

\author{
А. И. ЛУЧЕНОК \\ a.luchenok@gmail.com \\ докторр экономических наук, профессор, \\ заведующий отделом макроэкономической и финансовой политики \\ Институт экономики НАН Беларуси \\ г. Минск, Республика Беларусь \\ О. И. МОТОРИНА \\ matoryna@gmail.com \\ заведующий сектором анализа макроэкономической динамики \\ Институт экономики НАН Беларуси \\ г. Минск, Республика Беларусь
}

В статье авторы рассматривают вопрос реформирования институтов в рамках интеграчионных объединений как с теоретической, так и с практической точек зрения. На основе теории институциональных матрии обосновывается целесообразность использования опыта институционального реформирования стран - партнеров по интеграционной группировке. На основе расчета сводного индекса институционального развития стран, входящих в ЕАЭС, делается вывод о целесообразности применения в Беларуси опыта реформирования институтов России, Казахстана, Армении и Кыргызстана.

Ключевые слова: интеграция, институциональная среда, институциональная матрица, институциональная конвергенция, институты, институциональная динамика, сводный индекс институционального развития, импортирование институтов.

\title{
REFORMING OF INSTITUTIONS WITHIN THE FRAMEWORK OF THE INTEGRATION ASSOCIATION: THEORY AND PRACTICE FOR THE BELARUS
}

\author{
A.I. LUCHENOK \\ Doctor of Economic Sciences, Professor, Head of the Department of Macroeconomic \\ and Financial Policy \\ Institute of Economics of the National Academy of Sciences of Belarus \\ Minsk, Republic of Belarus \\ O. I. MOTORYNA \\ Head of the Sector of the Analysis of Macroeconomic Dynamics \\ Institute of Economics of the National Academy of Sciences of Belarus \\ Minsk, Republic of Belarus
}

In this article the authors consider the question of the reforming of the institutions within the framework of integration associations, both from the theoretical and from the practical point of view. On the basis of the theory of institutional matrix, the necessity to use the experience of institutional reform of partner countries in the integration group is justified. Based on the calculation of the consolidated index of institutional development of the countries included in the Eurasian Economic Union, a conclusion about the appropriateness of the application in 
the Belarus of Russia, Kazakhstan, Armenia and Kyrgyzstan's experience of institutions reforming is made.

Keywords: integration, institutional environment, institutional matrix, institutional convergence, institutions, institutional dynamics, consolidated index of institutional development, import of institutions.

\section{ВВЕДЕНИЕ}

Процесс интеграции - это сложное историческое явление со своими отличительными признаками и особенностями, сутью которого выступает формирование некой общности в результате определенных целенаправленных действий нескольких государств.

Существует много концепций, пытающихся объяснить феномен интеграции. Однако все они могут быть условно разделены на две группы: первая группа концепций пытается объяснить, почему возникают стимулы к интеграции, а вторая сосредотачивается на особенностях построения механизма управления уже интегрированной структуры. При этом необходимо отметить, что данные группы концепций во многом являются взаимообусловленными и комплементарными.

Своеобразный интегрированный подход к объяснению феномена интеграции, объединяющий в себе поиск ответов на вопросы, как об истоках, так и о результатах интеграции, может быть выработан в рамках институциональной теории.

\section{РЕЗУЛЬТАТЫ И ИХ ОБСУЖДЕНИЕ}

Социально-экономическая система любой страны представляет собой сложный конгломерат социально-экономических, политических и правовых отношений, регулирующий как поддержание развития экономики вообще, так и ее модернизации в частности. В такой ситуации особую роль приобретает согласование всех политических, правовых, экономических, социальных и экологических норм и правил в рамках проводимой институциональной политики. При этом институциональная политика обычно определяется как совокупность проводимых государством мер по формированию новых институтов, устранению старых или трансформации имеющихся экономических, правовых и идеологических норм и правил. Однако эффективность такой политики и ее роль в процессе модернизации экономики зависит от подхода к ее проведению.

В экономико-правой, идеологической и политической сфере все государства мира могут быть классифицированы по критерию взаимодействия государственно-правовых и рыночных отношений. В одних странах государство играет более существенную роль в регулировании экономических процессов. При этом в таких странах в идеологии и политике преобладает приоритет интересов общества над интересами отдельных личностей. В других странах сформировались так называемые «контрактные» отношения между государством и обществом, при которых считается, что граждане страны заключили с государством договор на обслуживание их потребностей. В них преобладают отношения индивидуализма, а приоритет рыночных отношений определяет специфику системы государственного регулирования. Правда, в кризисные периоды и в этих странах усиливается государственное регулирование, но оно все равно подчиняется интересам участников рыночных отношений.

Именно различные подходы к определению соотношения общественного и частного, государственно-правовых и рыночных отношений обусловливают специфику институциональной политики в отношении совокупности экономических, политических, 
социальных и юридических правил, образующих базис для производства, обмена и распределения. Эта специфика и определяет характер институциональной матрицы, на которой базируются общественные отношения в конкретной стране.

При формировании эффективных институциональных инструментов необходимо различать категории «институциональная среда» и «институциональная матрица».

Термин институциональная среда (institutional environment) активно использовался в трудах Д. Норта, который рассматривал институциональную среду как совокупность основополагающих политических, социальных и юридических правил, образующих базис для производства, обмена и распределения. Специфика институциональной системы определяется институциональной матрицей, на которой базируются общественные отношения в конкретной стране [1, с. 147-148].

Институциональная матрица - это исторически сложившаяся система базовых институтов, регулирующих взаимосвязанное функционирование основных общественных подсистем: экономики, права и идеологии. Институциональная матрица наряду с формальными (правовыми) нормами включает в себя и неформальные правила, сформировавшиеся с учетом национального менталитета и специфики исторического развития. Так, институциональная матрица страны, населением которой веками руководили абсолютные монархи, будет существенно отличаться от институциональной матрицы страны, граждане которой привыкли рассматривать государство как инструмент гарантирования их относительных политических и экономических свобод. Соответственно, в разных типах институциональных матриц роль государственно-правовых и рыночных институтов определяется по-разному.

Исследования показали, что в мире существуют два основных вида институционального устройства общества, отличающихся спецификой образующих их исходных матричных структур. В одном случае (X-матрица) доминируют государственно-правовые институты, а нормы, регулирующие рыночные отношения, являются хотя и важными, но вспомогательными инструментами. В другом случае (в институциональной Y-матрице) основная роль принадлежит рыночным отношениям, а государственно-правовое регулирование лишь обеспечивает устойчивое развитие рыночных механизмов. К странам, в которых преобладает централизованная иерархическая организация общества с приоритетом общегосударственных интересов и доминированием государства над рынком (Х-матрица), относятся Россия, Китай, Индия, страны Юго-Восточной Азии, Латинской Америки. Другая модель институционального устройства, при которой в обществе преобладают саморегулирующиеся структуры с приматом в общественном сознании частных интересов, а общие интересы реализуются на основе согласования частных интересов (Ү-матрица), доминирует в Западной Европе и США [2, с. 66-78].

В обобщенном виде, для определения того, к какой институциональной матрице относится государство, можно использовать таблицу 1.

Таблица 1 - Различия между Y- и X-матрицами

\begin{tabular}{|c|c|c|}
\hline & Y-матрица & X-матрица \\
\hline Экономическая сфера & $\begin{array}{c}\text { Преобладают институты } \\
\text { рынка, или обмена }\end{array}$ & $\begin{array}{c}\text { Преобладают институты неры- } \\
\text { ночной экономики }\end{array}$ \\
\hline Политическая сфрера & $\begin{array}{c}\text { Федеративное государственное } \\
\text { устройство }\end{array}$ & $\begin{array}{c}\text { Институты унитарно-централи- } \\
\text { зованного государственного } \\
\text { устройства }\end{array}$ \\
\hline
\end{tabular}


Окончание таблицы 1

\begin{tabular}{|l|c|c|}
\hline & $\boldsymbol{Y}$-матрица & $\boldsymbol{X}$-матрица \\
\hline \multirow{3}{*}{ Идеологическая сфера } & Доминирование личностных & Доминирование коллективных \\
& ценностей, т. е. примат лично- & сти, ее прав и свобод по отно- \\
& шению к ценностям сообществ. & ценностей, приоритет «Мы» \\
\hline
\end{tabular}

Источник: [3]

Поскольку Россия, Беларусь, Казахстан и другие страны Евразийского экономического союза базируются на X-матрице, то рассмотрим специфику взаимоотношения государства и рынка в этих странах:

- $\quad$ активно применяется практика административного перераспределения ресурсов, часто сопровождающаяся отрывом реальной цены активов от той суммы средств, по которой они перераспределяются. В рыночных условиях это создавало бы проблемы для эквивалентного обмена. Но поскольку рыночные отношения с самого начала в X-матрице рассматриваются как вспомогательный инструмент, то этот недостаток не является принципиальным;

- в государственно ориентированной институциональной модели возникают трудности импорта институтов, свойственных рыночной системе. Например, в страну могут быть импортированы рыночные принципы функционирования Центробанка, но, тем не менее, значительная часть ресурсов будет перераспределяться на льготных, отличных от рынка условиях;

- $\quad$ в X-матрице сильнее проявляются негативные эффекты проблемы асимметричности (недостаточности и неточности) информации. Это обусловлено свойством административных систем приукрашать свои результаты, что не может компенсироваться относительно слабо развитыми в таких системах рыночными отношениями.

Сторонники приоритета рыночных отношений хотели бы смены институциональной X-матрицы на Y-матрицу. Но институциональные матрицы весьма устойчивы и возможна только их революционная замена, сопровождающаяся временным снижением благосостояния домашних хозяйств, что отрицательно отражается на воспроизводственных процессах. Поэтому считаем, что в ближайшие годы не следует ожидать или провоцировать революционный переход в Республике Беларусь с X-матрицы на Ү-матрицу. Поэтому в основу совершенствования институциональной системы должно быть положено формирование эффективных институциональных инструментов, максимально эффективно согласующих интересы участников общественных отношений при сформировавшейся X-матрице.

Таким образом, модернизация экономики в странах на основе институциональной $\mathrm{X}$-матрицы - это не навязывание извне мало соответствующих специфике страны и менталитету людей норм и правил, а создание новых институциональных инструментов, в которых базовый институт по своей сущности сохраняет соответствие своей институциональной матрице, в то время как конъюнктурные, идеологические и мониторинговые институты подстраиваются под конкретные социально-экономические условия, в том числе обеспечивают развитие рыночных отношений до тех пор, пока они соответствуют господствующим в стране государственно-правовым условиям. При этом новые институциональные инструменты должны быть сопряжены с другими институциональными инструментами, действующими в сложившейся институциональной среде.

Мировая практика показывает, что все более-менее успешные интеграционные группировки создавались странами, относящимися к одной институциональной матрице. 
Таким образом, схожие институты стран, относящихся к одной институциональной матрице, являются предпосылкой для образования ими интеграционной группировки. Более того, определенный уровень институционального развития зачастую является и обязательным условием для вхождения какой-либо страны в интеграционное объединение.

Так, определенный уровень институционального развития являлся непременным условием присоединения к Европейскому союзу: кандидатам было необходимо соответствовать ряду политических (стабильность демократических институтов, верховенство закона, соблюдение прав человека, уважения прав меньшинств), экономических (страны-кандидаты должны иметь функционирующую рыночную экономику, а их производители должны быть способными справиться с конкурентным давлением в рамках Союза) правовых (се потенциальные члены должны привести свои законы в соответствие с принципами европейского права, формировавшимися на протяжении всей истории Союза) критериев.

Отдельно стоит отметить критерии для участия в валютных союзах - так называемые «критерии конвергенции». Соответствие им является непременным условием для обеспечения жизнеспособности и долговечности интеграционной группировки в форме валютного союза. Так, для стран ЕС критерии конвергенции Маастрихтского соглашения были следующие: странам не разрешалось иметь дефицит бюджета более $3 \%$ ВВП, а госдолг - выше $60 \%$ ВВП, причем данные значения должны были достигаться при отсутствии девальваций, при строго ограниченном росте инфляции и процентных ставок в национальной экономике. В ЕврАзЭС согласованные ограничения на значения макроэкономических показателей также имели место (дефицит госбюджета не более 4 \% ВВП, госдолг не более 80\% ВВП, инфляция не выше среднего показателя для трех стран с наименьшей инфляцией плюс 5 п.п. и др.), хотя и носили рекомендательный характер [4].

Таким образом, можно сказать, что обязательным условием принятия государства в валютный союз является достижение определенного уровня институтов (в первую очередь финансовых) страны.

Однако институциональная динамика является и результатом, или следствием интеграционных процессов. В данном случае интеграцию можно рассматривать в качестве внешнего фактора, влияющего на динамику развития национальных институтов. На институциональное развитие любого государства оказывают влияние не только внутренние (эндогенные), но и внешние (экзогенные) факторы. Интеграционные процессы и углубление международного разделения труда усиливают роль экзогенных факторов. Собственно национальное пространство институционального регулирования сужается. Особенно это характерно для малых открытых экономик. В качестве примера можно привести следующий исторический пример. Предполагаемое введение единых таможенных пошлин на ввоз автомобилей на территорию таможенного союза повлияло на состояние валютнофинансовой системы Беларуси. Согласно теории рациональных ожиданий, хозяйствующие субъекты увеличили закупки импортной техники, в результате увеличился спрос на валюту, что, в свою очередь, ускорило процесс девальвации белорусского рубля [5].

Таким образом, внешний фактор (намерение увеличить таможенные пошлины на ввоз автотранспорта) привело к существенному изменению финансовых институтов Беларуси без какого-либо существенного вмешательства местных органов денежно-кредитного регулирования.

Интеграция - это фактор экзогенного характера, влияющий на изменение норм и правил и, следовательно, динамику развития институтов. Внешнеэкономические связи (особенно, если они привели к созданию интеграционной группировки) приводят к возрастанию количества различных материально-правовых норм межстрановых соглашений, входящих в интеграционное объединение, в трансформированных в национальное 
законодательство. Сюда можно отнести как нормы, являющиеся объективными предпосылками вхождения национальных экономик в интеграционные структуры, так и нормы, принятые странами группировки в результате выработки общей таможенной, торговой, транспортной и др. политики. Принятие такие норм влияет на внутреннюю экономическую политику страны и на ее институциональную динамику.

Исследование показало, что для стран, входящих в одну интеграционную группировку, характерным является явление институциональной конвергенции, т. е. сближения условий ведения экономической деятельности и уровня развития институтов [6]. Так, на рисунке 1 представлена институциональная динамика стран, входящих в состав Евразийского экономического союза (ЕАЭС), рассчитанная на основании сводного индекса институционального развития [7]. Он показывает, что действительно, создание интеграционной группировки способствует сближению уровня развития институтов. На примере стран ЕАЭС видно, что уровень их институционального развития был достаточно близок в 1996 г. (самый ранний год, за который возможно произвести расчеты). Очевидно, это связано с тем, что до 1991 г. страны входили в состав СССР, и после его распада некоторое время еще сохранялась определенная схожесть национальных институтов (которые, как это неоднократно доказывалось, изменяются во времени достаточно медленно [8]). Однако постепенно разрыв между странами нарастал, и повторное сближение уровня развития институтов наблюдается после 2012 г., когда активизировались интеграционные процессы на постсоветском пространстве.

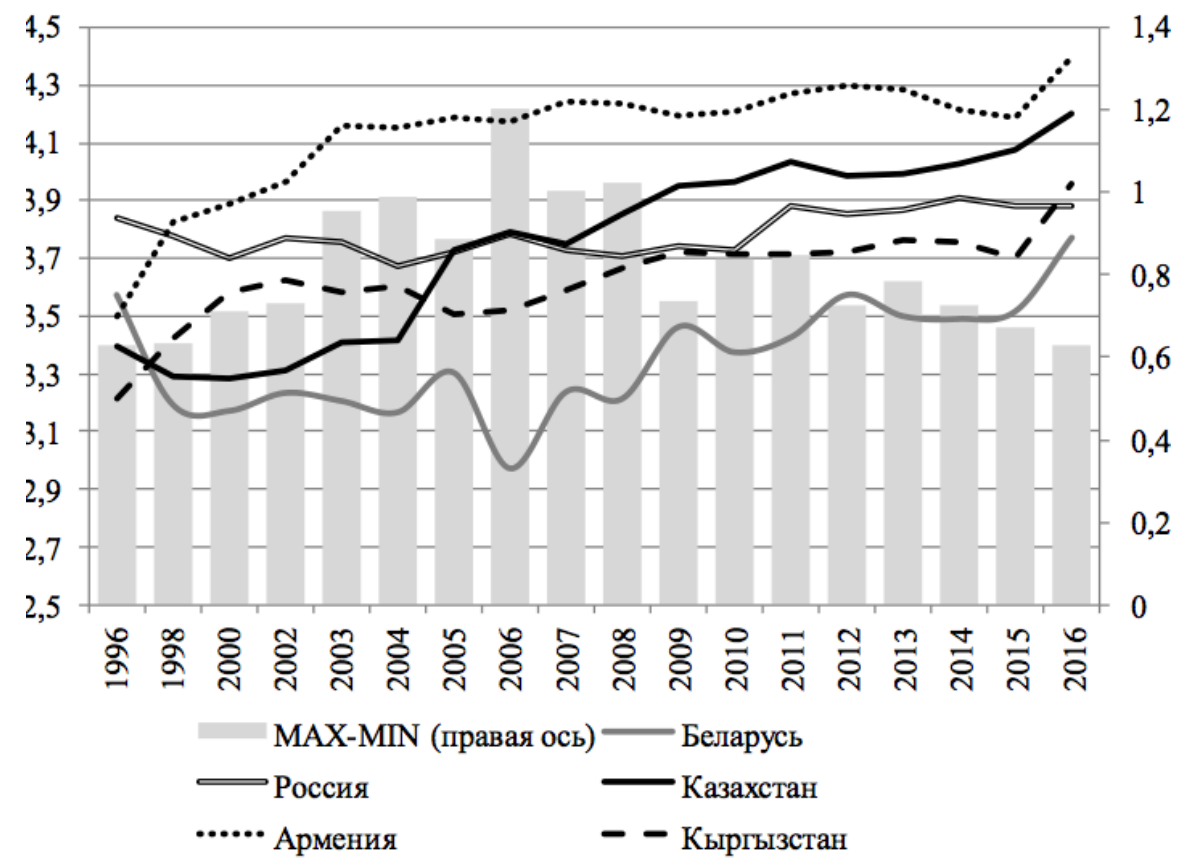

Рисунок 1 - Динамика развития институтов стран, входящих в состав ЕАЭС, $1996-2016^{*}$ гг., баллов

Примечание. Показатель «MAX-MIN» означает разнииу между максимальным и минимальным индексом институчионального развития среди стран ЕАЭС за определенный год. Источник: собственные расчеты

Тот же вывод подтверждает и анализ институциональной динамики «новых» членов Европейского союза (ЕС). На рисунке 2 представлены индексы институционального

\footnotetext{
* Сводный индекс институционального развития и его составляющие за 2016 г. рассчитан по предварительным данным.
} 
развития стран 11 «новых» членов $\mathrm{EC}^{*}$, вступивших в состав данного интеграционного объединения в 2004 (Чехия, Эстония, Венгрия, Литва, Латвия, Польша, Словакия, Словения), 2007 (Болгария, Румыния) и 2013 (Хорватия) годах. Рисунок 2 показывает, что в их случае также имеет место уменьшение разрыва между национальными уровнями институционального развития, причем наиболее интенсивно этот разрыв уменьшался именно с 2005 г., то есть после крупнейшего расширения ЕС.

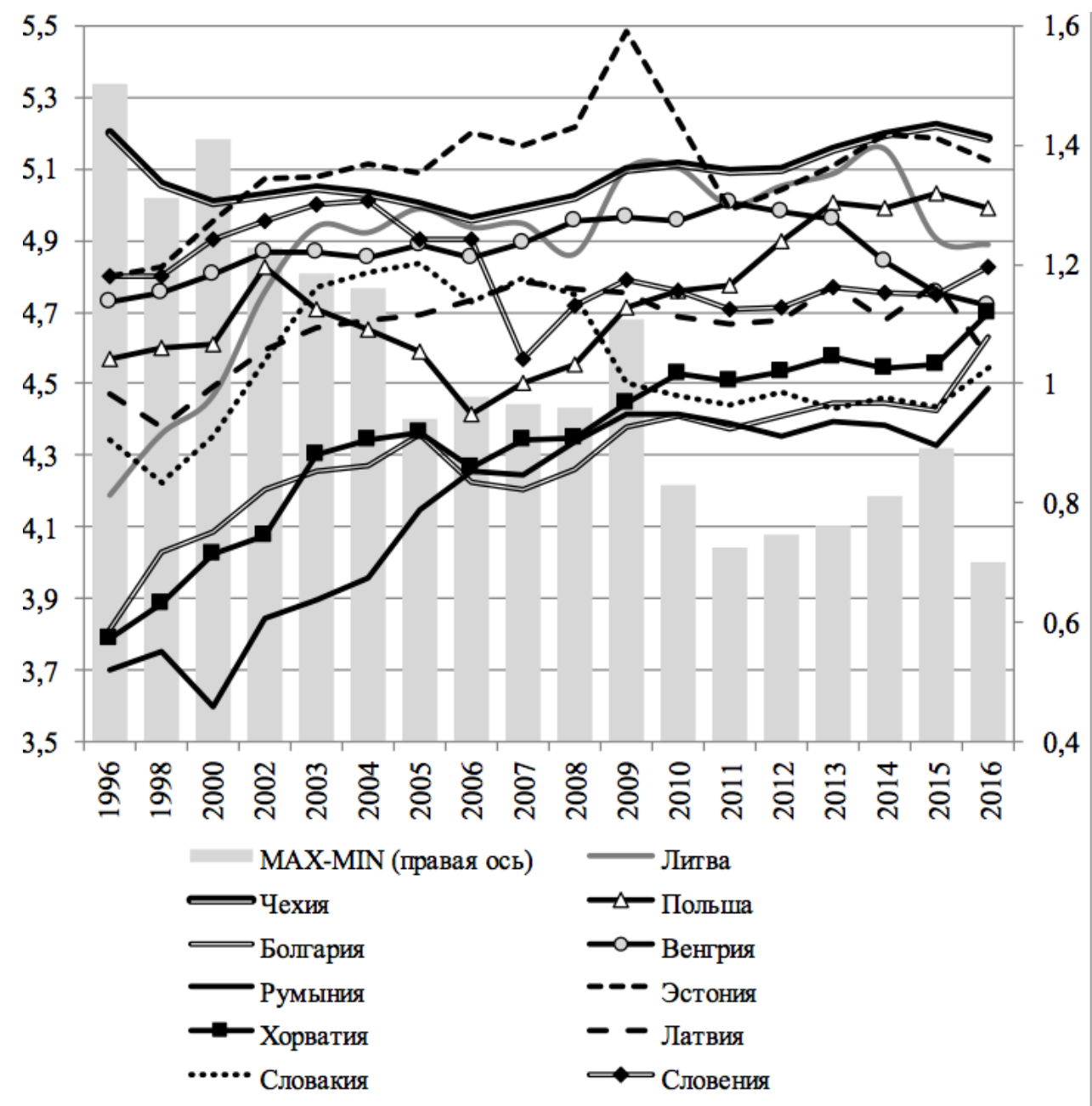

Рисунок 2 - Динамика развития институтов «новых» стран-членов ЕС, 1996-2016 гг., баллов

Примечание. Показатель «МАХ-MIN» означает разнииу между максимальным и минимальным индексом институциионального развития среди «новых» стран-членов ЕС за определенный год.

Источник: собственные расчеты

В качестве замечания следует обратить внимание на некоторое снижение либо очень медленную положительную динамику уровня институционального развития стран-лидеров интеграционной группировки, уровень институционального развития которых на момент ее создания был чаще всего наивысшим. Так, подобная ситуация имела место и в ЕАЭС (Россия), и в ЕС («старые» страны-члены ЕС-15). Одной из возможных

\footnotetext{
* Анализировались все «новые» члены ЕС, за исключением Мальты и Кипра, которые являются островными государствами и обладают рядом нехарактерных для большинства стран особенностей.
} 
причин данного явления (особенно в случае ЕС) может выступать доказанный ранее тезис о том, что уровень институционального развития развивающихся стран в большей степени подвержен колебаниям, чем уровень развитых стран, в связи с изначально более значительным высоким уровнем развития институтов [8]. Также не исключено, что обнаруженная стагнация в институциональном развитии стран-лидеров интеграционного объединения может быть связана с тем, что эти страны вынуждены в большей степени заниматься передачей накопленного опыта «новичкам», чем работать над повышением уровня развития собственных институтов.

Таким образом, мы показали, что институциональное развитие - это одновременно и предпосылка, и условие и следствие развития интеграционных процессов (рисунок 3 ).

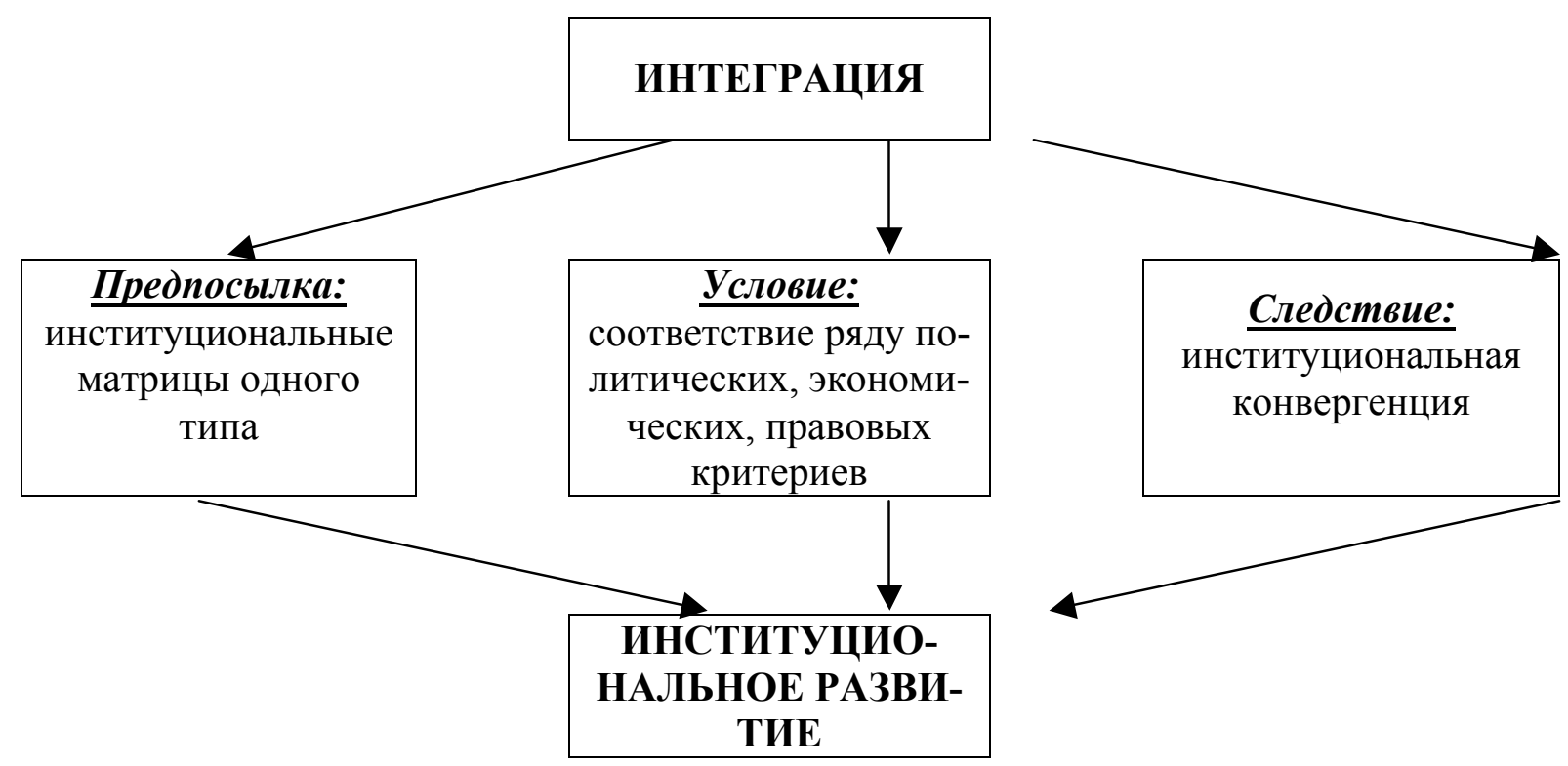

Рисунок 3 - Причинно-следственные связи между интеграцией и институциональным развитием

Источник: собственная разработка

Развитие ЕАЭС на современном этапе сталкивается с серьезными трудностями. В частности, существует ряд проблем, связанных с недостаточной отработкой институциональных подходов к интеграции. В аналитическом докладе Евразийской экономической комиссии 2015 г. признается: «Несмотря на то, что Договор о Союзе зафиксировал намерения государств-членов по постепенному сокращению изъятий и ограничений, в достаточно долгой перспективе внутренний рынок Союза будет функционировать в условиях их наличия» [9, с. 10].

Противоречия между странами-членами ЕАЭС можно сгладить при формировании в них единой институциональной среды. Как правомерно отметила А.С. Акопян, развитие интеграции в постсоветском пространстве объективно требует усиления регулирующей роли интеграционных институтов. Институты интеграции способствуют формированию сначала общего, затем единого институционального пространства взаимодействия экономических субъектов межгосударственного объединения с внедрением общих институциональных норм в каждом из государств [10, с. 231].

В странах, входящих в одно интеграционное объединение, где снято определенное количество барьеров между странами, импорт институтов происходит легче и есте- 
ственнее, следовательно, при формировании единой институциональной среды объединения необходимо использовать успешный опыт соседей по интеграционной группировке, связанный с государственным регулированием и реформированием институтов. Его применение с наибольшей степенью вероятности даст положительный результат.

Таким образом, для Беларуси целесообразнее всего будет изучение опыта государственного регулирования институциональной среды стран, входящих в ЕАЭС наиболее динамично развивающееся интеграционное объединение, действующее на постсоветском пространстве.

Таблица 2 показывает, что в настоящее время общий уровень институционального развития Беларуси наименее низкий среди всех стран ЕАЭС. Наиболее близки к ней по уровню развития институтов Россия и Кыргызстан, институты же Казахстана и Армении развиты существенно лучше.

Таблица 2 - Уровень институционального развития в целом и отдельных групп институтов стран ЕАЭС, 2016 г., баллов

\begin{tabular}{|c|c|c|c|c|c|}
\hline & $\begin{array}{c}\text { Правовые ин- } \\
\text { ститутьл }\end{array}$ & $\begin{array}{c}\text { Регулятивные } \\
\text { институтыл }\end{array}$ & $\begin{array}{c}\text { Институтьл } \\
\text { развития чело- } \\
\text { веческого капи- } \\
\text { тала }\end{array}$ & $\begin{array}{l}\text { Финансовые } \\
\text { институтыл }\end{array}$ & $\begin{array}{c}\text { Свод- } \\
\text { ныцй } \\
u \text { H }^{-} \\
\text {декс }\end{array}$ \\
\hline Россия & 3,22 & 4,49 & 3,49 & 4,33 & 3,88 \\
\hline Беларусь & 3,51 & 4,07 & 4,47 & 3,03 & 3,77 \\
\hline Казахстан & 3,55 & 4,68 & 3,80 & 4,78 & 4,20 \\
\hline Кыргызстан & 3,11 & 4,50 & 3,50 & 4,71 & 3,96 \\
\hline Армения & 3,75 & 5,00 & 3,39 & 5,46 & 4,40 \\
\hline
\end{tabular}

Примечание. Серым ияветом выделены показатели, превышающие соответствующий показатель Республики Беларусь.

Источник: собственные расчеты

В то же время следует отметить, что разные группы институтов Беларуси значительно отличаются по уровню развития. Так, республика имеет самый высокий показатель в ЕАЭС индекса институтов развития человеческого капитала. Правовые институты развиты лучше, чем в Беларуси, только в Казахстане и Армении. А вот по уровню развития регулятивных и финансовых институтов республика имеет наихудшие показатели в ЕАЭС.

Нет сомнений, что целесообразно применять опыт тех стран, которые добились лучших результатов в институциональном развитии, чем государство, которое рассматривает возможность применения зарубежного опыта институционального реформирования. Кроме того, институциональная динамика государства, опыт которого предполагается использовать, должна иметь положительный тренд. Более того, это государство предполагаемый экспортер институтов должно иметь более высокие показатели социально-экономического развития, чем страна, предполагающая использовать его опыт, причем уровень институционального развития должен непосредственно влиять на эти показатели. 


\section{ВЫВОДЫ}

Учитывая вышесказанное, можно предположить, что наибольший положительный эффект на ВВП Беларуси окажет применение положительного опыта развития институтов в Казахстане; опыт же России, Армении и Кыргызстана может быть использован скорее «точечно», в определенных аспектах, и его применение в Беларуси требует более тщательного изучения в каждой конкретной ситуации. К слову, тщательного изучения требует любой опыт, так как в любом случае недопустимо слепое «копирование» действий других стран без учета национальных особенностей.

Если попытаться импортировать в страну институты из другой институциональной матрицы, то возможно возникновение так называемых институциональных ловушек-ситуаций, когда любое управленческое решение приводит лишь к ухудшению ситуации. В качестве примера можно привести попытки внедрения в Беларуси индикативного планирования, на котором настаивают международные эксперты и сторонники рыночных реформ. Но в белорусской институциональной матрице X-типа не предполагает существенной децентрализации государственного управления, поэтому принятые решения по переходу к индикативному планированию затрудняют использование административно-директивных методов регулирования [10, с. 37]. Практика показала, что импортирование институтов, не свойственных белорусской институциональной матрице, оказывается неэффективным, хотя в странах с преимущественно рыночной ориентацией свойственные Y-матрице институты действенны и способствуют экономическому развитию.

\section{СПИСОК ИСПОЛЬЗОВАННЫХ ИСТОЧНИКОВ}

1. Норт, Д. Институты, институциональные изменения и функционирование экономики / Д. Норт. - М.: Фонд экономической книги «Начала». - 1997. - 180 с.

2. Кирдина, С. Г. Институциональные матрицы и развитие России. Введение в XY-теорию. Изд. 3-е, переработанное, расширенное и иллюстрированное / С. Г. Кирдина. М.; СПб.: Нестор-История, 2014. - 468 с.

3. Кирдина, С. Г. Институциональные матрицы: макросоциологическая объяснительная гипотеза [Электронный ресурс] / С. Г. Кирдина. - Режим доступа: http://www. kirdina.ru/index.php?option=com_content\&view=article\&id=221. - Дата доступа: 29.03.2018.

4. Шеголева, Н. Г. Валютный союз: разработка оптимальных «критериев конвергенции» [Электронный ресурс] / Н. Г. Шеголева, Д. А. Балашов. - Режим доступа: https://cyberleninka.ru/article/v/valyutnyy-soyuz-razrabotka-optimalnyh-kriteriev-konvergen tsii. - Дата доступа: 27.03.2018.

5. Громыко, Р. И. Влияние процессов интеграции на институциональное развитие страны [Электронный pecypc] / Р. И. Громыко. - Режим доступа: https://elib.gstu.by/ bitstream/handle/220612/10536/\%20\%20\%20\%20\%20\%20\%20,\%20\%20.\%20\%20.\%20\%20 $\% 20 \% 20 \% 20 \% 20 \% 20 \% 20 \% 20 \% 20 \% 20 \% 20 \% 20 \% 20 \% 20 \% 20 \% 20 \% 20 \ldots .$. pdf? sequence $=1$. Дата доступа: 26.03.2018.

6. Пелипась, И. Реальная, номинальная и институциональная конвергенция в странах ЕАЭС [Электронный ресурс] / И. Пелипась. - Режим доступа: http://www. research.by/webroot/delivery/files/wp2017r03.pdf. - Дата доступа: 04.04.2018.

7. Моторина, О. И. Методические основы анализа институциональной динамики Беларуси / О. И. Моторина // Банкаўскі веснік. - 2017. - № 6 (647). - С. 43-53.

8. Моторина, О. И. Анализ институционального развития Беларуси / О. И. Моторина // Банкаўскі веснік. - 2018. - № 3 (656). - С. 19-24. 
9. Аналитический доклад Евразийской экономической комиссии «О ситуации по устранению препятствующих функционированию внутреннего рынка Евразийского экономического союза барьеров для взаимного доступа, а также изъятий и ограничений в отношении движения товаров, услуг, капитала и рабочей силы» [Электронный ресурс]. - М., 2015. - 106 c. - Режим доступа: http://goo.gl/JFvMlD. - Дата доступа: 25.04.2018.

10. Лученок, А. И. Институты правят экономикой / А. И. Лученок; Нац. акад. наук Беларуси, Ин-т экономики. - Минск: Беларуская навука, 2018. - 279 с.

\section{REFERENCES}

1. Nort, D. Instituty, institucional'nye izmeneniya i funkcionirovanie ehkonomiki / D. Nort. - M.: Fond ehkonomicheskoj knigi «Nachala». - 1997. - $180 \mathrm{~s}$.

2. Kirdina, S. G. Institucional'nye matricy i razvitie Rossii. Vvedenie v H-Y-teoriyu. Izd. 3-e, pererabotannoe, rasshirennoe i illyustrirovannoe / S. G. Kirdina. - M.; SPb.: NestorIstoriya, 2014. $-468 \mathrm{~s}$.

3. Kirdina, S. G. Institucional'nye matricy: makrosociologicheskaya ob"yasnitel'naya gipoteza [EHlektronnyj resurs] / S. G. Kirdina. - Rezhim dostupa: http://www.kirdina.ru/index.php?option=com_content\&view=article\&id=221. - Data dostupa: 29.03.2018.

4. Shegoleva, N. G. Valyutnyj soyuz: razrabotka optimal'nyh «kriteriev konvergencii» [Ehlektronnyj resurs] / N. G. SHegoleva, D. A. Balashov. - Rezhim dostupa: https://cyberleninka.ru/article/v/valyutnyy-soyuz-razrabotka-optimalnyh-kriteriev-konvergentsii. - Data dostupa: 27.03.2018.

5. Gromyko, R. I. Vliyanie processov integracii na institucional'noe razvitie strany [Ehlektronnyj resurs] / R. I. Gromyko. - Rezhim dostupa: https://elib.gstu.by/bitstream/handle/ $220612 / 10536 / \% 20 \% 20 \% 20 \% 20 \% 20 \% 20 \% 20, \% 20 \% 20 . \% 20 \% 20 . \% 20 \% 20 \% 20 \% 20 \% 20 \% 20$ $\% 20 \% 20 \% 20 \% 20 \% 20 \% 20 \% 20 \% 20 \% 20 \% 20 \% 20 \% 20 \ldots$.pdf? sequence=1. - Data dostupa: 26.03.2018.

6. Pelipas', I. Real'naya, nominal'naya i institucional'naya konvergenciya $\mathrm{v}$ stranah EAEHS [Ehlektronnyj resurs] / I. Pelipas'. - Rezhim dostupa: http://www.research.by/ webroot/delivery/files/wp2017r03.pdf. - Data dostupa: 04.04.2018.

7. Motorina, O. I. Metodicheskie osnovy analiza institucional'noj dinamiki Belarusi / O. I. Motorina // Bankay̆ski vesnik. - 2017. - № 6 (647). - S. 43-53.

8. Motorina, O. I. Analiz institucional'nogo razvitiya Belarusi / O. I. Motorina // Bankay̆ski vesnik. - 2018. - № 3 (656). - S. 19-24.

9. Analiticheskij doklad Evrazijskoj ehkonomicheskoj komissii «O situacii po ustraneniyu prepyatstvuyushchih funkcionirovaniyu vnutrennego rynka Evrazijskogo ehkonomicheskogo soyuza bar'erov dlya vzaimnogo dostupa, a takzhe iz"yatij i ogranichenij v otnoshenii dvizheniya tovarov, uslug, kapitala i rabochej sily» [EHlektronnyj resurs]. - M., 2015. 106 s. - Rezhim dostupa: http://goo.gl/JFvMlD. - Data dostupa: 25.04.2018.

10. Luchenok, A. I. Instituty pravyat ehkonomikoj / A. I. Luchenok; Nac. akad. nauk Belarusi, In-t ehkonomiki. - Minsk: Belaruskaya navuka, 2018. - 279 s.

Статья поступила в редакичию 29 августа 2018 года. 